\title{
The challenges of human resources in mental health in Kenya
}

\author{
DIM Ndetei ${ }^{1}$, FA Ongecha ${ }^{2}$, V Mutiso ${ }^{3}$, M Kuria ${ }^{4}$, LI Khasakhala ${ }^{5}$, DA Kokonya ${ }^{6}$ \\ ${ }^{1}$ University of Nairobi, Kenya \& Director, Africa Mental health Foundation. \\ ${ }^{2}$ Coast Provincial General Hospital, \& Research Associate, Africa Mental Health Foundation. \\ ${ }^{3}$ University of Nairobi \& Research Associate, Africa Mental Health Foundation. \\ ${ }^{4}$ University of Nairobi, Kenya \& Research Associate, Africa Mental Health Foundation. \\ ${ }^{5}$ Department of Psychiatry, University of Nairobi, Kenya \& Research Associate, Africa Mental Health Foundation. \\ ${ }^{6}$ Kakamega Provincial General Hospital \& Research Associate, Africa Mental Health Foundation
}

\begin{abstract}
Objective: Africa faces a skills shortage, in spite of training suitably qualified professionals. This is particularly evident in the discipline of Psychiatry. An analysis of the distribution and availability of psychiatrists in Kenya was thus conducted and findings compared with specific other African countries (Uganda and Zimbabwe). Method: Questionnaire, emailed to Heads of Academic Departments within the specified countries. Results: In 2004, there were a total of 53 psychiatrists practicing in Kenya, for a population of 31.5 million. The country has about 4,000 medical practitioners, with psychiatrists constituting $0.013 \%$ of the total number of medical practitioners. This is equivalent to a psychiatrist: population ratio of 1:594,339; doctor: population ratio of 1:7,875; a psychiatrist: overall doctors' ratio of $1: 75.5$, that is only $1.325 \%$ of Kenyan doctors are psychiatrists. When the psychiatrist: population ratios are considered on the basis of the provinces, then the ratios vary from 1:63,007 in the capital city of Nairobi to 1:4,393,19 in other provinces, with one without a psychiatrist for a population of 962,143 . The ratios decline further when psychiatrists available for clinical work in public facilities are considered. Up to 34\% (n=18) of all Kenyan psychiatrists were in private practice. The remaining $66 \%(n=35)$ were in the public sector, of whom more than 20 were in full time administrative or academic positions and therefore not available for full time clinical work in the public sector. Locally trained psychiatrists, compared with foreign trained psychiatrists, fared better on: non-migration to other countries, working in rural rather the urban areas, working in public rather than private sector and in overall academic achievements. Conclusion: In the fore-seeable future in Kenya it will not be possible to achieve a psychiatrist: population ratio equivalent to that in Western countries, both in terms of overall ratio for the country, and more importantly, for the average distribution within the country. For the needs of Kenya, and other developing countries, local training of psychiatrists is superior to foreign training in several parameters. If Kenya and other similar developing countries in Africa are to achieve realistic mental health service delivery in the foreseeable future, alternative non-specialist training in mental health is required. Conflict of Interest: None. This study was conceptualized by DMN. It formed the basis of the Key Note speech at the WHO Regional Conference of Psychiatrists, Arusha, Tanzania 2004. It was funded by the Africa Mental Health Foundation (AMHF).
\end{abstract}

Keywords: Kenya, Questionnaire, Mental health

Received: 08.06.2005

Accepted: 27.10 .2006

\section{Introduction}

Kenya has performed relatively well in the training of Psychiatrists in Africa. The 1997 WHO data on psychiatrist: population ratios for several countries in Africa (Table I) support this. However, these ratios are extremely poor

\section{Correspondence:}

Prof. David M. Ndetei

University of Nairobi, Kenya \& Director, Africa Mental Health Foundation (AMHF), P.O. Box 48423-00100 Nairobi, Kenya. Tel: (+254)-020-2716315, Fax (+254)-020-2717168. email: dmndetei@mentalhealthafrica.com or

dmndetei@mail.unobi.ac.ke compared to Western countries, where for example in the USA the ratio is in the region of 1:7000. ${ }^{1}$ However, overall country statistics (including those of Western countries) reflect little of the realities on the ground. ${ }^{1}$

The phenomenon of brain drain from developing to developed countries is a reality ${ }^{2}$, more so in view of the declining training of psychiatrists in the West. ${ }^{3,4}$ The Department of Psychiatry, University of Nairobi,has been involved in the training of psychiatrists since 1983, and the programme has gained momentum ever since. ${ }^{2}$ There is therefore the need for Kenya, and other similar developing countries, to review what is happening on the ground vis-vis what is happening on the global scene, and to begin to 
Table I: Ratio of psychiatrists to population (selected countries in Sub-Saharan Africa), mid 1997:

\begin{tabular}{|l|l|l|l|}
\hline Country & $\begin{array}{l}\text { Population } \\
\text { (Million) }\end{array}$ & $\begin{array}{l}\text { Number of } \\
\text { Psychiatrists }\end{array}$ & $\begin{array}{l}\text { Psychiatrist/ } \\
\text { Population ratio }\end{array}$ \\
\hline Uganda & 20.6 & 11 & $1: 1,1,872,700$ \\
Tanzania & 29.5 & 11 & $1: 2,681,800$ \\
Kenya ** & 28.8 & 56 & $1: 514,200$ \\
Rwanda & 7.7 & 1 & $1: 7,700,000$ \\
Nigeria *** & 102.1 & 100 & $1: 1,021,000$ \\
Ethiopia & 58.7 & 11 & $1: 5,336,300$ \\
Zambia & 9.4 & 2 & $1: 4,700,000$ \\
Zimbabwe & 11.4 & 10 & $1: 4,140,000$ \\
Malawi & 9.6 & 1 & $1: 9,600,000$ \\
Mauritius & 1.1 & 9 (all Government) & $1: 122,200$ \\
Cameroon & 13.9 & 4 & $1: 3,475,000$ \\
Ghana & 18 & 11 & $1: 1,636,300$ \\
\hline
\end{tabular}

*Source: 1997 World Population Data sheet publication of Population

Reference Bureau Washington DC.

1998 WHO Africa Mental Action Newsletter

** Only one medical school training psychiatrists

*** More than 10 medical schools training psychiatrists

strategize for a sustainable, appropriate and realistic provision of mental health services in the years to come.

\section{METHOD}

A questionnaire to document the number of psychiatrists, where they trained, in which countries they practiced, and for Kenya - their predominant roles as psychiatrists and locations of practice within Kenya was developed by the lst author (DMN). This questionnaire also enquired as to the population of the respective countries, and for Kenya the respective regions, as well as a breakdown of the contents of the curriculum for the postgraduate training in psychiatry and hours allocated to psychiatry and mental health at undergraduate medical education. This questionnaire was sent to the heads of academic departments of psychiatry at several universities to complete for their countries, in consultation with appropriate government authorities. ${ }^{5}$

This questionnaire was sent electronically, and those
Table II: Distribution of Kenyan psychiatrists per type of facility (April 2004):

\begin{tabular}{|l|l|}
\hline Facility type & No. of psychiatrists \\
\hline Public health facility & $22(1$ an expatriate) \\
University(Teaching) & 13 \\
Private Practice & 18 \\
\hline Total & 53 \\
\hline
\end{tabular}

completed were returned the same way. The Kenyan population for any year is based on the yearly projections by the Kenya population council.

\section{RESULTS}

The questionnaires were fully completed only for three countries, Kenya, Uganda and Zimbabwe. The findings will focus on the Kenyan data. There were 53 psychiatrists working in Kenya in 2004. Table II summarizes the distribution of these psychiatrists as per type of facility and where they worked.

Table IIIa summarizes the distribution of psychiatrists, all of them located in the major urban areas, as well as the population in those urban areas. Some urban areas had better psychiatrist: population ratio than Nairobi, the capital city. However some of these urban areas were in fact settlements in rural areas, thus serving those rural areas, and could therefore be regarded as rural.

Table IIIb summarizes the distribution of psychiatrists in rural and urban areas and whether those psychiatrists were in

\begin{tabular}{|c|c|c|c|}
\hline & Private & Public & Total \\
\hline $\begin{array}{l}\text { Rural } \\
\text { Urban }\end{array}$ & $\begin{array}{l}2 \\
16\end{array}$ & $\begin{array}{l}7 \\
28\end{array}$ & $\begin{array}{l}9 \\
44\end{array}$ \\
\hline Total & 18 & 35 & 53 \\
\hline
\end{tabular}

\begin{tabular}{|c|c|c|c|c|c|c|}
\hline \multicolumn{7}{|c|}{$\begin{array}{l}\text { Table III a: Distribution of psychiatrists in Kenya in urban areas (April 2004) } \\
*=\text { Administrative capitals. Note One administrative capital is not included because it did not have a psychiatrist }\end{array}$} \\
\hline \multirow[t]{2}{*}{ Town } & \multicolumn{6}{|c|}{ No. of psychiatrists } \\
\hline & Public & Private & Total & $\begin{array}{l}\% \text { of all psychiatrists } \\
\text { in the country }\end{array}$ & population $^{a}$ & $\begin{array}{l}\text { Psychiatrist } \\
\text { population ratio }\end{array}$ \\
\hline $\begin{array}{l}\text { Nairobi * } \\
\text { Eldoret } \\
\text { Mombasa* } \\
\text { Machakos } \\
\text { Kisumu* } \\
\text { Nakuru* } \\
\text { Thika } \\
\text { Embu* } \\
\text { Meru } \\
\text { Nkubu } \\
\text { Nyeri* } \\
\text { Kakamega* }\end{array}$ & $\begin{array}{l}24 \\
4 \\
1 \\
2 \\
1 \\
1 \\
1 \\
1 \\
0 \\
0 \\
0 \\
0\end{array}$ & $\begin{array}{l}10 \\
0 \\
3 \\
0 \\
0 \\
0 \\
0 \\
0 \\
1 \\
1 \\
2 \\
1\end{array}$ & $\begin{array}{l}34 \\
4 \\
4 \\
2 \\
1 \\
1 \\
1 \\
1 \\
1 \\
1 \\
2 \\
1\end{array}$ & $\begin{array}{l}64.1 \\
7.5 \\
7.5 \\
3.8 \\
1.9 \\
1.9 \\
1.9 \\
1.9 \\
1.9 \\
1.9 \\
3.8 \\
1.9\end{array}$ & $\begin{array}{l}2,143,254 \\
197,449 \\
665,018 \\
143,274 \\
322,734 \\
231,262 \\
106,707 \\
52,446 \\
126,427 \\
7,725 \\
101,238 \\
74,115\end{array}$ & $\begin{array}{l}1: 63036 \\
1: 49362 \\
1: 166,254 \\
1: 71,637 \\
1: 322,734 \\
1: 231,262 \\
1: 106,707 \\
1: 52,446 \\
1: 126,427 \\
1: 7,725 \\
1: 50,619 \\
1: 14,115\end{array}$ \\
\hline Total & 35 & 18 & 53 & 100 & $4,042,749$ & $1: 1,990,324$ \\
\hline
\end{tabular}


the private (available only to those who could afford private treatment) or public sector (theoretically available only to those who seek services in Government funded facilities). Only 17\% were in rural areas and the rest were all based in the major urban areas.

When the distributions of psychiatrists are considered on the basis of major administrative areas (inclusive of both rural and urban) i.e. provinces then the psychiatrists: population ratios vary greatly (Table IV). One had no psychiatrist at all and two had one psychiatrist for more than a population of 2 million (Table IV should be considered along side Tables IIIa and IIIb which indicated clearly where such psychiatrists are based and whether in the private or public sector).

\section{TableIV: The Distribution of psychiatrists per province\# (April 2004).}

\begin{tabular}{|l|l|l|l|l|}
\hline Province & Psychiatrist & $\%$ & population & $\begin{array}{l}\text { Psychiatrist per } \\
\text { population }\end{array}$ \\
\hline 1 Nairobi & 34 & 64.1 & $2,143,254$ & $1: 63,007$ \\
2 Central & 3 & 5.7 & $3,724,159$ & $1: 124,1386$ \\
3 Coast & 4 & 7.5 & $2,487,264$ & $1: 621,816$ \\
4 Eastern & 5 & 9.4 & $4,631,779$ & $1: 926,355$ \\
5 North Eastern & 0 & 0 & 962,143 & - \\
6 Nyanza & 1 & 1.9 & $4,392,196$ & $1: 4,392,196$ \\
7 Rift Valley & 5 & 9.4 & $6,987,036$ & $1: 1,397,407$ \\
8 Western & 1 & 1.9 & $3,358,776$ & $1: 3,358,776$ \\
\hline
\end{tabular}

\#Kenya is divided into 8 administrative units called provinces

Table V summarizes what those psychiatrists predominantly do. Only 23 out of the 53 (i.e. 43.4\%) were involved in full time clinical work.

Table VI summarizes the number of Kenyan psychiatrists known to be practicing at the time of the survey, regardless of which country they practiced in 2004. There were a total of 73. Of these, 21 (29\%), nearly a third were practicing outside Kenya. Those who trained outside Kenya , 17 out of 26 i.e. $65.4 \%$, practiced outside Kenya while for the equivalent of those trained in Kenya only 4 out of 47 (8.5\%) practiced outside Kenya

Table VII gives an indication on the content of training for psychiatrists for three countries (Kenya, Uganda and Zimbabwe). Kenya allocated the most number of hours for
Table VI: Location of Kenyan psychiatrists by place of training (April 2004).

\begin{tabular}{|c|c|c|c|}
\hline & Overseas trained & Kenyan trained & Total \\
\hline $\begin{array}{l}\text { In public Services } \\
\text { in Kenya }\end{array}$ & 4 & 30 & $\begin{array}{l}34 \text { (excluding } 1 \\
\text { expatriate) }\end{array}$ \\
\hline $\begin{array}{l}\text { In private practice } \\
\text { in Kenya }\end{array}$ & 5 & 13 & 18 \\
\hline Overseas & 17 & 4 & 21 \\
\hline Total & 26 & 47 & 73 \\
\hline
\end{tabular}

Table VII Training hours for Master of Medicine in Psychiatry (April 2004).

\begin{tabular}{l|l|l|l|}
\hline & Kenya & Uganda & Zimbabwe \\
\hline $\begin{array}{l}\text { Behavioral Sciences Psychiatry } \\
\text { Adult }\end{array}$ & - & 300 & 699 \\
Child/Adolescent & 25 & 195 & 3 months \\
Psycho-geriatrics & & 195 & 3 months \\
Community psychiatry & $10 *$ & 195 & 0 \\
Forensic psychiatry & 195 & 2 months \\
Substance psychiatry & Not specified & 195 & 2 months \\
Liaison psychiatry & 40 & 195 & 0 \\
Psychology & 10 & 150 & 0 \\
Pharmacotherapy & $20 *$ & 90 & 1 month \\
Neurology & 135 & 3 months \\
Health Systems Medicine & 75 & 45 & 1 week-full \\
Research & time per \\
Epidemiology, Biostatistics & & year x 3 \\
Research Methods & & \\
\hline * 3 month attachment in the respective departments. \\
** During the entire study period of 3 years the students undertakes full time \\
clinical work at the mental hospital.
\end{tabular}

research based training. For all the three countries, a research dissertation on a topic relevant to clinical practice or policy is part of the training and must be successfully completed.

\section{DISCUSSION}

As of 2004, Kenya had a total of 73 psychiatrists of whom only 53 practiced in Kenya, giving Kenya one of the best psychiatrist: population ratios in Africa, South of Sahara and outside South Africa. ${ }^{5}$ It is noteworthy that in 1997, the Kenyan psychiatrist:

Table V: Distribution of public service psychiatrists by predominant role: (April 2004).

\begin{tabular}{|c|c|c|c|c|c|c|c|}
\hline Facility & Total No. & & & & & & \\
\hline- & - & Administration & Teaching & $\begin{array}{l}\text { On going Research } \\
\text { dissertation } \\
\text { Supervision }\end{array}$ & Clinical work & $\begin{array}{l}\text { Research } \\
\text { (excluding } \\
\text { supervision of } \\
\text { Dissertation }\end{array}$ & Station \\
\hline $\begin{array}{l}\text { 1. Ministry of Health } \\
\text { 2. World Health } \\
\text { Organization } \\
\text { 3. Mathari Hospital } \\
\text { 4. University of Nairobi } \\
\text { 5. Moi University } \\
\text { 6. Moi Hospital } \\
\text { 7. Nyanza } \\
\text { 8. Coast } \\
\text { 9. Machakos } \\
\text { 10. Embu } \\
\text { 11. Thika } \\
\text { 12. Nakuru }\end{array}$ & $\begin{array}{l}2 \\
1 \\
7 \\
8 \\
1 \\
3 \\
1 \\
1 \\
1 \\
1 \\
1 \\
1\end{array}$ & $\begin{array}{l}2 \\
1 \\
2 \\
1 \\
1 \\
1 \\
1 \\
1\end{array}$ & $\begin{array}{l}- \\
- \\
- \\
1 \\
1 \\
3\end{array}$ & 5 & $\begin{array}{l}5 \\
8 \\
1 \\
3 \\
1 \\
1 \\
1 \\
1 \\
1 \\
1\end{array}$ & $\begin{array}{l}- \\
3 \\
3 \\
\text { Not known } \\
\text { Not known }\end{array}$ & $\begin{array}{l}\text { Nairobi } \\
\text { Nairobi } \\
\text { Nairobi } \\
\text { Nairobi } \\
\text { Eldoret } \\
\text { Eldoret } \\
\text { Kisumu } \\
\text { Mombasa } \\
\text { Machakos } \\
\text { Embu } \\
\text { Thika } \\
\text { Nakuru }\end{array}$ \\
\hline
\end{tabular}


population ratio was 1:514,200 (Table I). At the time of the current survey (2004) it was 1:543,396. As of July 2006 there are 63 psychiatrists practicing in the country with a current of population of 33.3 million, giving a ratio of $1: 528,571$. Thus the 1997, 2004 and 2006 statistics suggest negligible change in the ratios over the last ten years. This scenario is likely to be repeated over longer periods of time in spite of the apparent growing popularity of psychiatry among medical students and as an area of specialization at postgraduate level.

The significance of the African and Kenyan ratios can be compared with the Western countries. In 2002, there were approximately 14 clinically active psychiatrists per 100,000 population in the USA, giving a ratio of psychiatrist: population of $1: 7143$. If the ratio in Kenya was to compare with that of the USA, 4690 psychiatrists would be required, against the current 63 in the country, more than 50\% of whom are not clinically available on a full time basis. Kenya, like other developing countries must therefore re-think its options.

Although these ratios are inadequate compared with those found in Western countries, they need to be further viewed within the context of the intra-country variation in Kenya and the actual availability of psychiatrists for clinical work, especially in the public sector . Most of the psychiatrists are resident in urban areas, regardless of which region in Kenya is under consideration. Only a small fraction are available for full time clinical work, with the majority of those available for full time clinical work being in full time private practice. This leaves the public sector relatively lacking in full time psychiatrists. These realities on the ground are not necessarily peculiar to Kenya, and the Kenyan situation illustrates how the overall psychiatrist: population ratio can be very misleading, which has been noted in the case of the USA. ${ }^{1}$

That nearly one third of Kenyan psychiatrists practice outside Kenya re-emphasizes the reality of the brain drain, as has been recently highlighted. ${ }^{6}$ This study found that it was most likely to occur when the psychiatrists had trained outside Kenya and in particular in the West, compared with locally trained psychiatrists i.e. those locally trained were more likely to remain in the country, be available to work outside of Nairobi as well as perform academic functions (especially research). It may well be that the requirement for locally trained psychiatrists to complete research and dissertations as part of their training contributes to their greater involvement with academic functions. It has been argued, with the South African setting, that without academic psychiatry there would ultimately be no meaningful psychiatric services. ${ }^{7}$

Considering that the recruitment into psychiatry is already low in the West ${ }^{4}$ and forecast that psychiatry will fall short of demand for psychiatrists in the West "for years to come", together with increasing globalization of the world market, Kenya and the developing countries must address this reality. Kenya and other developing countries with weak economies will continue to train psychiatrists for the open market. ${ }^{3}$ This amounts to transfer of financial and human resources to the West - a case of the poor supporting the rich.

Kenya and other developing countries must therefore seriously consider shifting resources so as to allocate a significant component of their resources for mental health training of medical students and non-specialist medical personnel. Kenya has a turnover of about 300 medical graduates annually. If adequately equipped to handle mental health problems at the level they are trained to handle medical and pediatric problems, both in community and rural areas, the return on resource allocation might likely be greater than resources spent on training one psychiatrist, who may even not work in the country. The same argument might well apply even more strongly for other non-specialist medical personnel.

Mental health research should be part of any specialist training progamme for psychiatry. Such training might enhance the application of evidence based practice and policy, as well as on how best to allocate resources for mental health personal training. Those trained psychiatrists who opt to stay and work in their home countries will, for years to come, out of necessity and expediency, be those who beyond clinical service delivery are likely best utilized for providing leadership in research, teaching, policy making and administration.Whilst not a specific focus of the current study, research would seem most important, for it is research that will inform core activities i.e. the best clinical practice. Most fundamentally, it is research that will provide guidance on the kind of research that should be prioritized in developing countries.

\section{Conclusion}

Kenyan psychiatry is under resourced in terms of personnel, which appears to be the case for most African countries relative to those in the developed world. In addition to psychiatrists providing clinical service, consideration needs to be given to improving the clinical skills related to mental health care delivery at both an under and post graduate level, so as to develop a broader resource of practitioners capable of rendering mental health care services.

\section{Acknowledgements}

Prof. Mohamed Sebit of University of Zimbabwe for coordinating the data for Zimbabwe, Dr. Fred Kigozi for coordinating the data for Uganda and Dr. John Mburu for coordinating the data for Kenya. Africa Mental Health Foundation (AMHF) supported the concept development, data coordination and all write-ups; Grace Mutevu of the AMHF for analyzing the data.

\section{References}

1. Duffy FF, et al. Mental Health Practitioners and Trainees. In: Mental Health, United States, US Department of Health and Human Services. DHSS Publication NO. (SMA) 3938, 2002 (Printed 2004).

2. Ndetei DM. The Walk towards the promise: A View of Mental Health in Global, Kenyan and Individual Perspectives. Inaugural Lecture, University of Nairobi, Kenya. 2001

3. Weissman SH, Haynes RA, Killian CD, et al. A model to determine the influence of medical school on students' career choices. Psychiatry: a case study. Academic Medicine 1994; 69:58-59.

4. Sierles FS, Taylor MA. Decline of U.S. medical student career choice of psychiatry and what to do about it. American Journal of Psychiatry 1995; 152:1416-1426.

5. Ndetei DM. Audit on training and research in medical schools in Africa. Monograph, Africa Mental Health Foundation, Nairobi. 2004.

6. Ndetei D, Karim S, Mubbashar M. Recruitment of Consultant psychiatrists from low- and middle-income countries. International Psychiatry 2004; Issue 6: 5-18.

7. Szabo CP. Psychiatry in South Africa: some reflections. South African Psychiatry Review 2006; 9(3): 121-125. 